Acta Regionalia et Environmentalica 2

Nitra, Slovaca Universitas Agriculturae Nitriae, 2017, pp. 64-69

\title{
ANALYSIS OF SELECTED ENVIRONMENTAL INDICATORS IN THE CULTIVATION SYSTEM OF ENERGY CROPS
}

\author{
Božena ŠOLTYSOVÁ*, Martin DANILOVIČ
}

National agricultural and food centre - Agroecology Research Institute Michalovce, Slovak Republic

\begin{abstract}
The changes of selected chemical parameters were observed in Gleyic Fluvisols. The field experiment was established as a twofactor experiment with four energy crops (Arundo donax L., Miscanthus x giganteus, Elymus elongatus Gaertner, Sida hermafrodita) and two variants of fertilization (nitrogen fertilization in rate $60 \mathrm{~kg} \mathrm{ha}^{-1}$, without nitrogen fertilization). Soil samples were taken from the depth of 0 to $0.3 \mathrm{~m}$ at the beginning of the experiment in the autumn 2012 and at the end of reference period in the autumn 2015. Land management conversion from market crops to perennial energy crops cultivation has influenced changes of selected soil chemical parameters. The contents of soil organic carbon were affected by cultivated energy crops differently. It was found out that Arundo increased the organic carbon content and Miscanthus, Elymus and Sida decreased its content. At the same time, the same impact of the crops on content of available phosphorus and potassium and soil reaction was found. It was recorded that each cultivated crop decreased the soil reaction and available phosphorus content and increased the content of available potassium.
\end{abstract}

Keywords: energy crops; soil; organic carbon; humus substances; soil reaction; available nutrients

Environmental indicators are an important means in the process of assessing the state of the environment and the development of the environment and are also related to sustainable development of environment. Indicators are measurable variables that inform about development and trends. The strategic objectives of sustainable development in relation to the environment also include mitigation of the impact of global climate change, reduction of energy and raw materials and reduction of the use of non-renewable natural resources.

The quality of the environment and the air purity are threatened by the consequences of human activity. Land use leads to a reduction in carbon stock in the pedosphere. Carbon in form of carbon dioxide issues from the soil and increases gas concentration in the atmosphere (Chesworth, 2008). Atmospheric carbon dioxide has increased from 100 ppmv since preindustrial times to $385 \mathrm{ppmv}$ at present (Lüthi et al., 2008).

The ratification of the Kyoto Protocol and the subsequent legislative adaptation in term of its reduction targets and the introduction of a wide range of measures have led to a steady reduction in carbon dioxide emissions in Slovakia. The amount of $\mathrm{CO}_{2}$ emissions in Slovakia fell by $14.1 \%$ in 2012 compared to 2000 (Guštafíková et al., 2014).

Climate change is related to soil degradation, soil organic matter degradation, soil structure change, infiltration speed change and the increase in available nutrients content. In Slovakia, degradation threatens up to $70 \%$ of the soil (Kobza, 2014). Soil degradation has a gradual and cumulative character. The threat to the soil is also caused by the decline in available nutrients related with their negative balance, as well as the deterioration of other chemical and physical parameters of the soil.

There are many strategies to increase the soil carbon stock and two of them are energy crops cultivation and no-till soil management (Lal, 2004). Perennial energy crops cultivation combine both of the mentioned strategies, because there is no soil cultivation during productive years, besides cultivation before planting. Growing energy crops has the potential to mitigate carbon dioxide emissions by the replacement of fossil fuels and also by storing carbon in the soil due to land use change.

In terms of carbon balance, energy crops increase carbon stocks in arable land (Davis et al., 2010; Don et al., 2012; Zimmermann et al., 2012). Carbon accumulation under energy crops is similar to that under perennial grasses (Anderson-Teixeira et al., 2009) or under native pastures (Dondini et al., 2009). For example, Miscanthus can yearly incorporate up to $0.59 \pm 0.16 \mathrm{t} \mathrm{ha}^{-1}$ year $^{-1} \mathrm{C}$ in to the soil (Clifton-Brown et al., 2007)

The removal of natural vegetation to make space for energy crops could release large contents of carbon dioxide into the atmosphere, especially through deforestation (Danielsen et al., 2009). It was found out that conversion of uncultivated natural land to biofuel agriculture resulted in significant soil organic carbon losses (Anderson-Teixeira et al., 2009). Conversion of agricultural land to energy crops seems to be a better way in terms of carbon balance. Carbon losses from the soil when converting farmland as well as natural stands are dependent on plant species (Schneckenberger and Kuzyakov, 2007; Hillier et al., 2009). The different soil utilization affects not only the changes 
in soil parameters, but also the quality of the production (Duffková et al., 2005; Symanowicz et al., 2014; Kron et al., 2017).

The aim of this study was to evaluate the changes of selected soil chemical parameters in the energy crops grown on the Gleyic Fluvisols.

\section{Material and methods}

The field experiment was initiated in 2012 at experimental station of the National agricultural and food centre Agroecology Research Institute, which is located in Milhostov ( $\left.48^{\circ} 40^{\prime} \mathrm{N}, 21^{\circ} 43^{\prime} \mathrm{E}\right)$. The experimental station is situated in the central part of the East-Slovak Lowland at an altitude of $101 \mathrm{~m}$. The average annual temperature is $8.9^{\circ} \mathrm{C}$ (16.0 ${ }^{\circ} \mathrm{C}$ during vegetation period) and average annual rainfall is $560 \mathrm{~mm}$ ( $350 \mathrm{~mm}$ during vegetation period). The soil is Gleyic Fluvisols. According to the Novak classificatory scale (Zaujec et al., 2009), this soil subtype belongs to medium heavy and clayey-loamy soils (average content of clay particles is $41 \%)$.

The average values of chemical properties of the topsoil (depth from 0 to $0.3 \mathrm{~m}$ ) measured before starting the experiment were: soil total acidity $10 \mathrm{mmol} \mathrm{kg}{ }^{-1}$, amount of exchange basic cations $320 \mathrm{mmol} \mathrm{kg}{ }^{-1}$, total sorption capacity $330 \mathrm{mmol} \mathrm{kg}^{-1}$, degree of saturation of the sorption complex $97 \%$, total nitrogen content $1.5 \mathrm{~g} \mathrm{~kg}^{-1}$, available phosphorus content $95 \mathrm{mg} \mathrm{kg}^{-1}$, available potassium content $230 \mathrm{mg} \mathrm{kg}^{-1}$, available magnesium content $295 \mathrm{mg} \mathrm{kg}^{-1}$, exchangeable calcium content $4,700 \mathrm{mg} \mathrm{kg}^{-1}$, soil reaction (in $1 \mathrm{~mol} \mathrm{dm}^{-3} \mathrm{KCl}$ ) 6.7 , humus content $2.5 \%$, the type of humus is from humate-fulvic to fulvic-humate with humic acids and fulvic acids ratio from 0.6 to 1.1.

The field experiment was established as a two-factor experiment with four energy crops: Arundo donax L., Miscanthus $\times$ giganteus, Elymus elongatus Gaertner, Sida hermafrodita and two variants of fertilization: FV - variant with nitrogen fertilization in rate $60 \mathrm{~kg} \mathrm{ha}^{-1}$, NV - variant without nitrogen fertilization. In both variants, phosphorus $\left(40 \mathrm{~kg} \mathrm{ha}^{-1}\right)$ and potassium $\left(60 \mathrm{~kg} \mathrm{ha}^{-1}\right)$ were applied each year in spring. The energy crops were fertilized with a combination of fertilizers: Amofos (12\% N, 22.7\% P), ammonium nitrate $(27.5 \% \mathrm{~N})$ and potassium chloride (50\% K). The variant size was $12 \mathrm{~m}^{2}$ for Arundo, Miscanthus, Sida and $9 \mathrm{~m}^{2}$ for Elymus and each variant was three times repeated.

Soil samples were collected in the depths of 0 to $0.3 \mathrm{~m}$ in the autumn 2012 (at the beginning of the experiment) and in the autumn 2015 (at the end of reference period). The disturbed soil samples were analysed using well-known methodologies to determine the following chemical soil parameters: soil organic carbon was determined by the Tjurin method (Hraško et al., 1962), contents of humic acids and fulvic acids by Kononovova and Bel'čikova (Hrivňáková et al., 2011), available phosphorus and potassium by the Mehlich III method (Mehlich, 1984) and exchange soil reaction in $1 \mathrm{~mol} \mathrm{dm}^{-3} \mathrm{KCl}$ solution (Hrivňáková et al., 2011).

The multi-factorial analysis of variance (ANOVA) was used to evaluate treatment effects on selected soil parameters. Differences between treatments means were assessed by the least significant difference (LSD) test. All statistical analyses were performed using the Statgraphics software package.

\section{Results and discussion}

The quantitative and qualitative status of soil organic matter is the result of long-term soil-forming processes. In the central part of the East-Slovak Lowland climatic conditions, the decomposition processes are depends on the chemical composition of plant residues. In the case of energy crops, the soil organic carbon content ranged from 14.15 to $14.88 \mathrm{~g} \mathrm{~kg}^{-1}$ (Table 1) and after conversion to the humus its content corresponded to the medium stock (Fecenko and Ložek, 2000).

The soil organic carbon content was not significantly dependent on a year. A slight decrease in soil organic carbon by $0.13 \mathrm{~g} \mathrm{~kg}^{-1}$ was found between the years under review. The changes in organic carbon content in the soil were affected by the cultivated energy crops. Compared to the baseline, the decline in soil organic carbon in Elymus $\left(-0.28 \mathrm{~g} \mathrm{~kg}^{-1}\right)$ and Sida $\left(-0.25 \mathrm{~g} \mathrm{~kg}^{-1}\right)$ was recorded in 2015. Changes in the content of soil organic carbon were minimal in Arundo and Miscanthus, compared to the starting year. The decline in organic matter in the soil is considered to be the most important factor in soil degradation.

Organic matter content in the soil is strongly influenced by selection of a crop. Different crops contain different amounts and quality of humus-forming material is different, too. The decrease in soil organic carbon in Elymus and Sida was probably related to the lower crops yield and therefore to the lower carbon input by roots and by harvest residues. The average dry matter yield (three-year average) found in Elymus was $14.88 \mathrm{t} \mathrm{ha}^{-1}$ and Sida $19.37 \mathrm{t} \mathrm{ha}^{-1}$, but in Arundo $21.09 \mathrm{t} \mathrm{ha}^{-1}$ and Miscanthus $27.43 \mathrm{t} \mathrm{ha}^{-1}$.

At the same time, soil organic carbon content was also influenced by the changes in weather conditions. Air temperature indirectly affects the soil organic carbon content by the influence on the soil microbial activity (Zhang et al., 2007). Higher air temperatures accelerate the decomposition of soil organic matter and decrease its content. Alvarez and Lavado (1998) report that the carbon content in the soil decreases with increasing temperature and it increases with increasing precipitation. The average year air temperature was above normal during the evaluated period, in 2013, it was much above normal and in 2014 and 2015 it was extraordinarily above normal. The higher air temperature was probably a contributing cause for decline in organic carbon in the soil (Table 2). A significant negative dependence $(r=-0.31)$ was determined between air temperature during the vegetation periods and organic carbon content in the soil. Marriott and Wander (2006) also found a negative dependence between air temperature and organic carbon in the soil. The precipitation was different in each evaluated years and their vegetation periods. A positive significant dependence $(r=0.32)$ was found between precipitation during vegetation period and organic carbon content in the soil. The obtained results support the statement of Alvarez and Lavado (1998) that raising precipitation increases the carbon content in soil. 
Table 1 Measuring data of selected soil parameters in the energy crops

\begin{tabular}{|c|c|c|c|c|c|c|c|c|c|}
\hline \multirow[t]{4}{*}{ Parameters } & \multirow[t]{4}{*}{ Years } & \multicolumn{8}{|c|}{ Energy crops } \\
\hline & & \multicolumn{2}{|c|}{ Arundo } & \multicolumn{2}{|c|}{ Miscanthus } & \multicolumn{2}{|c|}{ Elymus } & \multicolumn{2}{|c|}{ Sida } \\
\hline & & \multicolumn{8}{|c|}{ fertilization } \\
\hline & & FV & NV & FV & NV & FV & NV & FV & NV \\
\hline \multirow{3}{*}{$C_{o x}\left(g_{k g}^{-1}\right)$} & 2012 & 14.15 & 14.27 & 14.66 & 14.67 & 14.85 & 14.64 & 14.88 & 14.86 \\
\hline & 2015 & 14.26 & 14.22 & 14.55 & 14.69 & 14.52 & 14.42 & 14.65 & 14.59 \\
\hline & $\Delta$ & 0.11 & -0.05 & -0.11 & 0.02 & -0.33 & -0.22 & -0.23 & -0.27 \\
\hline \multirow{3}{*}{$\mathrm{C}_{\mathrm{HS}}\left(\mathbf{g ~ k g}^{-1}\right)$} & 2012 & 4.06 & 4.10 & 4.63 & 4.52 & 4.46 & 4.38 & 4.47 & 4.37 \\
\hline & 2015 & 4.18 & 4.14 & 4.68 & 4.72 & 4.58 & 4.41 & 4.40 & 4.33 \\
\hline & $\Delta$ & 0.12 & 0.04 & 0.05 & 0.20 & 0.12 & 0.03 & -0.07 & -0.04 \\
\hline \multirow{3}{*}{$\mathrm{C}_{\mathrm{HA}}\left(\mathbf{g ~ k g}^{-1}\right)$} & 2012 & 1.96 & 2.03 & 2.05 & 2.05 & 2.19 & 2.03 & 2.16 & 2.18 \\
\hline & 2015 & 2.12 & 2.15 & 2.22 & 2.23 & 2.32 & 2.15 & 2.23 & 2.24 \\
\hline & $\Delta$ & 0.16 & 0.12 & 0.17 & 0.18 & 0.13 & 0.12 & 0.07 & 0.06 \\
\hline \multirow{3}{*}{$C_{\mathrm{FA}}\left(\mathbf{g ~ k g}^{-1}\right)$} & 2012 & 2.10 & 2.08 & 2.59 & 2.47 & 2.27 & 2.35 & 2.31 & 2.19 \\
\hline & 2015 & 2.06 & 1.99 & 2.46 & 2.48 & 2.26 & 2.26 & 2.18 & 2.09 \\
\hline & $\Delta$ & -0.04 & -0.09 & -0.13 & 0.01 & -0.01 & -0.09 & -0.13 & -0.10 \\
\hline \multirow{3}{*}{$\begin{array}{l}\text { pH } \\
\left(1 \mathrm{~mol} \mathrm{dm}^{-3} \mathrm{KCl}\right)\end{array}$} & 2012 & 6.83 & 6.82 & 6.71 & 6.69 & 6.68 & 6.68 & 6.65 & 6.65 \\
\hline & 2015 & 6.70 & 6.71 & 6.64 & 6.66 & 6.66 & 6.64 & 6.61 & 6.61 \\
\hline & $\Delta$ & -0.13 & -0.11 & -0.07 & -0.03 & -0.02 & -0.04 & -0.04 & -0.04 \\
\hline \multirow{3}{*}{$P\left(\mathbf{m g ~ k g}{ }^{-1}\right)$} & 2012 & 104.2 & 103.9 & 97.4 & 98.4 & 90.2 & 87.5 & 93.9 & 95.3 \\
\hline & 2015 & 104.0 & 98.5 & 91.5 & 96.4 & 84.1 & 80.7 & 84.8 & 85.5 \\
\hline & $\Delta$ & -0.2 & -5.4 & -5.9 & -2.0 & -6.1 & -6.8 & -9.1 & -9.8 \\
\hline \multirow{3}{*}{$K\left(\mathbf{m g ~ k g}{ }^{-1}\right)$} & 2012 & 207.2 & 214.0 & 231.2 & 231.2 & 230.0 & 227.7 & 241.2 & 237.5 \\
\hline & 2015 & 226.1 & 234.3 & 247.2 & 248.1 & 250.6 & 250.2 & 255.5 & 253.0 \\
\hline & $\Delta$ & 18.9 & 20.3 & 16.0 & 16.9 & 20.6 & 22.5 & 14.3 & 15.5 \\
\hline
\end{tabular}

$\mathrm{C}_{\mathrm{ox}}$ - soil organic carbon; $\mathrm{C}_{\mathrm{HS}}$ - humus substances carbon; $\mathrm{C}_{\mathrm{HA}}$ - humic acids carbon; $\mathrm{C}_{\mathrm{FA}}$ - fulvic acids carbon; $\mathrm{pH}$ in $1 \mathrm{~mol} \mathrm{dm}^{-3}$ $\mathrm{KCl}$ - exchange soil reaction; $\mathrm{P}$ - available phosphorus; $\mathrm{K}$ - available potassium; $\mathrm{FV}$ - variant fertilized with nitrogen in rate $60 \mathrm{~kg} \mathrm{ha}^{-1} \mathrm{~N} ; \mathrm{NV}$ - variant without nitrogen fertilization; $\Delta$ - difference 2015-2012

Table 2 Statistical evaluation of selected soil parameters in the energy crops

\begin{tabular}{|l||c|c|c|c|c|c|c|c|}
\hline \multirow{2}{*}{$\begin{array}{l}\text { Source } \\
\text { variability }\end{array}$} & \multirow{2}{*}{ Factor } & \multicolumn{7}{|c|}{ Observed parameter } \\
\cline { 2 - 9 } & & $\mathbf{C}_{\mathbf{o x} .}$ & $\mathbf{C}_{\mathbf{H S}}$ & $\mathbf{C}_{\mathbf{H A}}$ & $\mathbf{C}_{\mathbf{F A}}$ & $\mathbf{p H}$ & $\mathbf{P}$ & $\mathbf{K}$ \\
\hline \hline \multirow{3}{*}{ Crop } & Arundo & $14,22 \mathrm{a}$ & $4.12 \mathrm{a}$ & $2.06 \mathrm{a}$ & $2.06 \mathrm{a}$ & $6,76 \mathrm{~b}$ & $102,7 \mathrm{~d}$ & $220,4 \mathrm{a}$ \\
\cline { 2 - 10 } & Miscanthus & $14,64 \mathrm{~b}$ & $4.64 \mathrm{c}$ & $2.14 \mathrm{ab}$ & $2.50 \mathrm{c}$ & $6,67 \mathrm{a}$ & $95,9 \mathrm{c}$ & $239,4 \mathrm{~b}$ \\
\cline { 2 - 10 } & Elymus & $14,61 \mathrm{~b}$ & $4.46 \mathrm{~b}$ & $2.17 \mathrm{ab}$ & $2.28 \mathrm{~b}$ & $6,66 \mathrm{a}$ & $85,6 \mathrm{a}$ & $239,6 \mathrm{~b}$ \\
\cline { 2 - 10 } & Sida & $14,75 \mathrm{~b}$ & $4.39 \mathrm{~b}$ & $2.20 \mathrm{~b}$ & $2.19 \mathrm{ab}$ & $6,63 \mathrm{a}$ & $89,9 \mathrm{~b}$ & $246,8 \mathrm{C}$ \\
\hline \multirow{3}{*}{ Fertilization } & $\mathrm{FV}$ & $14,57 \mathrm{a}$ & $4.43 \mathrm{a}$ & $2.16 \mathrm{a}$ & $2.28 \mathrm{a}$ & $6,68 \mathrm{a}$ & $93,8 \mathrm{a}$ & $236,1 \mathrm{a}$ \\
\cline { 2 - 10 } & $\mathrm{NV}$ & $14,55 \mathrm{a}$ & $4.37 \mathrm{a}$ & $2.13 \mathrm{a}$ & $2.24 \mathrm{a}$ & $6,68 \mathrm{a}$ & $93,3 \mathrm{a}$ & $237,0 \mathrm{a}$ \\
\hline \multirow{3}{*}{ Year } & 2012 & $14,62 \mathrm{a}$ & $4.37 \mathrm{a}$ & $2.08 \mathrm{a}$ & $2.29 \mathrm{a}$ & $6,71 \mathrm{~b}$ & $96,4 \mathrm{a}$ & $227,5 \mathrm{a}$ \\
\cline { 2 - 11 } & 2015 & $14,49 \mathrm{a}$ & $4.43 \mathrm{a}$ & $2.21 \mathrm{~b}$ & $2.22 \mathrm{a}$ & $6,65 \mathrm{a}$ & $90,7 \mathrm{~b}$ & $245,6 \mathrm{~b}$ \\
\hline
\end{tabular}

$\mathrm{C}_{\mathrm{ox} \text {. }}$ - soil organic carbon; $\mathrm{C}_{\mathrm{HS}}$ - humus substances carbon; $\mathrm{C}_{\mathrm{HA}}$ - humic acids carbon; $\mathrm{C}_{\mathrm{FA}}$ - fulvic acids carbon; $\mathrm{pH}$ - exchange soil reaction; $\mathrm{P}$ - available phosphorus; $\mathrm{K}$ - available potassium; $\mathrm{FV}$ - variant fertilized with nitrogen in rate $60 \mathrm{~kg} \mathrm{ha}^{-1} \mathrm{~N} ; \mathrm{NV}$ - variant without nitrogen fertilization; letters $(a, b, c$, d) between factors refer to statistically significant differences $(\alpha=0.05)$ - LSD test 
By modelling the development of soil organic matter content, it has been found out that under current management methods, the development of its content is still pessimistic (Barančíková et al., 2010). However, organic matter losses from the soil may not be permanent. Existing remedial practices for organic matter storage in soil can contribute to reducing or suspending excessive releases of carbon into the air. These remedies may even provide a positive balance of carbon in the soil and are simply called carbon sequestration (Bielek and Jurčová, 2010). Average annual increases of soil organic matter by carbon sequestration range from $1.38 \mathrm{t} \mathrm{ha}^{-1}$ to $17.0 \mathrm{t} \mathrm{ha}^{-1}$. Carbon sequestration into the soil can be achieved by corrections on both sides of the carbon balance, i.e. by reducing the intensity of mineralization of soil organic matter and by increasing carbon inputs into the soil through the regulations in crop rotation and increased doses of the organic fertilizers and organic waste materials. It was assumed that the change in land management, the conversion to the perennial energy crops cultivation, would allow the storage of carbon in the soil. In Arundo, an increase in soil organic carbon by the average of $0.05 \mathrm{~g} \mathrm{~kg}^{-1}$ was found during the study period, which, after conversion, represents an insignificant increase by $0.225 \mathrm{t} \mathrm{ha}^{-1} \mathrm{C}$ in the top soil $(0.3 \mathrm{~m})$. In Miscanthus, the soil organic carbon content decreased by an average of $0.08 \mathrm{~g} \mathrm{~kg}^{-1}$, which represents a decrease of only $0.360 \mathrm{t} \mathrm{ha}^{-1} \mathrm{C}$ in the top soil $(0.3 \mathrm{~m})$ for three years. The decline in the soil organic carbon between 2012 and 2015 was also found in Elymus $\left(-0.28 \mathrm{~g} \mathrm{~kg}^{-1}\right)$ and Sida $\left(-0.25 \mathrm{~g} \mathrm{~kg}^{-1}\right)$, which, after conversion, represents for three years a carbon loss of $1.260 \mathrm{t} \mathrm{ha}^{-1}$ in Elymus and $1.125 \mathrm{t} \mathrm{ha}^{-1}$ in Sida in the top soil $(0.3 \mathrm{~m})$. The lower dry matter yield was attained in the first two to three years after the establishment of perennial energy crops, and therefore lower amounts of the roots and postharvest residues remain in the soil. It is hypothesized that higher input of organic carbon from the root and postharvest residues will be in the older crops that produce higher yield the organic carbon balance will be at least balanced or slightly positive.

The soil organic matter content does not increase by the application of industrial fertilizers. If the postharvest residues remain in the soil and industrial fertilizers are applied too, the soil organic carbon content increased indirectly by increasing the biomass production of the plants (Tobiášová and Šimanský, 2009). The observed changes in soil organic carbon content in the fertilized variant were similar to those of the variant without fertilization. The decline in soil organic carbon on average by $0.14 \mathrm{~g} \mathrm{~kg}^{-1}$ in the fertilized variant and by $0.13 \mathrm{~g} \mathrm{~kg}^{-1}$ in the unfertilized control was recorded in 2015 compared to the initial level. Three year average of dry matter yield was $22.87 \mathrm{t} \mathrm{ha}^{-1}$ in the Arundo, $31.71 \mathrm{t} \mathrm{ha}^{-1}$ in the Miscanthus, $16.58 \mathrm{t} \mathrm{ha}^{-1}$ in the Elymus and $23.77 \mathrm{t} \mathrm{ha}^{-1}$ in the Sida at the variant with nitrogen fertilization. At variant without fertilization the average of dry matter yields were lower (Arundo $19.31 \mathrm{t} \mathrm{ha}^{-1}$, Miscanthus $23.14 \mathrm{t} \mathrm{ha}^{-1}$, Elymus $13.18 \mathrm{t} \mathrm{ha}^{-1}$, Sida $\left.14.96 \mathrm{t} \mathrm{ha}^{-1}\right)$.

Simultaneously with the mineralization of the organic matter in the soil the humification process is taking place, in which specific nitrogen containing humus compounds are formed (Hůla and Procházková et al., 2008). Humus compounds in form of humic acids and fulvic acids constituted up to $29.9 \%$ in the soil organic carbon in 2012 and exceeded $30.6 \%$ in the soil organic carbon at the end of the research period. The total content of humus compounds significantly depends on the crop (Table 2). The carbon content of humus compounds increased after three years of Miscanthus ( $\left.+0.13 \mathrm{~g} \mathrm{~kg}^{-1}\right)$, Arundo and Elymus $\left(+0.08 \mathrm{~g} \mathrm{~kg}^{-1}\right)$ cultivation. Contrary, the carbon content of humus compounds decreased by $0.06 \mathrm{~g} \mathrm{~kg}^{-1}$ after three years cultivation of Sida. The increase in humus compounds was related with significant increase in more stable humic acids. The highest increase of humic acids was found out in Miscanthus ( $+0.18 \mathrm{~g} \mathrm{~kg}^{-1}$ ) in comparison with Arundo and Elymus $\left(+0.14 \mathrm{~g} \mathrm{~kg}^{-1}\right.$, resp. $\left.+0.13 \mathrm{~g} \mathrm{~kg}^{-1}\right)$. At the same time, these crops showed a comparable decrease in less stable fulvic acids. The decrease in the humus compounds in the soil in Sida was associated with the lowest increase in the humic acids and the highest decline in the fulvic acids.

The close correlations between the organic carbon content and the humus compounds identified Horáček et al. (2005). Significant, slightly positive dependence $(r=0.48)$ was confirmed between organic carbon and humus compounds in the soil after the energy crops cultivation. Positive dependence was formed by humic acids $(r=0.26)$ and mainly by fulvic acids $(r=0.39)$.

The soil reaction and the nutrient contents belong to the soil parameters affecting its fertility. The exchange soil reaction ranged between 6.61 to 6.83 for the cultivation of perennial energy crops and this range is classified as neutral with respect to the assessment criteria (Act no. 151/2016 Coll.). A significantly higher soil reactions were measured at the beginning of the experiment in 2012. Insufficient replacement of annual calcium losses caused a moderate decrease in soil reaction from 6.71 to 6.65 in 2015 (Table 1). Annual losses of calcium from the soil, by leaching, by the crop planting, by the fertilizers and by the rain are reported by Bizík et al. (1998) at the level of $350 \mathrm{~kg} \mathrm{ha}^{-1} \mathrm{CaO}$. To prevent soil acidification, regular soil liming is necessary. With the current trend, the soil reaction may be reduced more rapidly in the following years. The highest decrease in soil reaction (0.12) was found in Arundo. A lower decrease in soil reaction was found in Miscanthus, Elymus and Sida, the soil reaction in all three crops was comparable (from 0.03 to 0.05$)$.

In terms of criteria for the evaluation of chemical analysis of the arable soils (Act no. 151/2016 Coll.), the detected content of available phosphorus in the soil in energy crops was classified from satisfactory to good content and the available potassium content as good. The content of available phosphorus and potassium in the soil in our experiment depended only on the uptake by crops. The content of available phosphorus decreased by $5.7 \mathrm{mg} \mathrm{kg}^{-1}$ in the soil in energy crops (Table 2). Differences in the content of the available phosphorus in the soil were found between the evaluated years in all monitored crops. The lowest drop in phosphorus was found in Arundo (-2.8 mg kg-1) and Miscanthus (-4.0 mg kg-1), higher in Elymus $\left(-6.5 \mathrm{mg} \mathrm{kg}^{-1}\right.$ ) and the highest in Sida $\left(-9.5 \mathrm{mg} \mathrm{kg}^{-1}\right)$. Conversely, in the case of available potassium, a significant increase by $18.1 \mathrm{mg} \mathrm{kg}^{-1}$ was found between the baseline and the final year of the experiment. The different trend in potassium and phosphorus contents probably caused diametrically 
different amounts of deposition. Dry and wet deposition of potassium is about 30 to $40 \mathrm{~kg}$ per hectare and year, while the phosphorus is only about a kg per hectare and year (Kováčik, 2001).

The detected changes in available nutrients content were comparable at the different fertilization variants. The phosphorus content decreased by $5.3 \mathrm{mg} \mathrm{kg}^{-1}$ in the fertilized variant and by $6.0 \mathrm{mg} \mathrm{kg}^{-1}$ in the variant without fertilization. The potassium content increased by $17.5 \mathrm{mg} \mathrm{kg}^{-1}$ in the fertilized variant and by $18.8 \mathrm{mg} \mathrm{kg}^{-1}$ in the variant without fertilization. The difference between the variants of fertilization was not significant for both nutrients.

\section{Conclusions}

The change in land management, the conversion to the perennial energy crops cultivation, was reflected in changes in the soil organic carbon content depending on the cultivated crop. In Arundo, the increase in soil organic carbon by an average of $0.05 \mathrm{~g} \mathrm{~kg}^{-1}$ was found during the study period, which, after conversion, represents the insignificant increase by $0.225 \mathrm{t} \mathrm{ha}^{-1} \mathrm{C}$ in the top soil $(0.3 \mathrm{~m})$. In Miscanthus, the soil organic carbon content decreased by an average of $0.08 \mathrm{~g} \mathrm{~kg}^{-1}$, which represents the decrease of only $0.360 \mathrm{t} \mathrm{ha}^{-1} \mathrm{C}$ in the top soil $(0.3 \mathrm{~m})$ for three years. The decline in the soil organic carbon between 2012 and 2015 was also found in Elymus $\left(-0.28 \mathrm{~g} \mathrm{~kg}^{-1}\right)$ and Sida $\left(-0.25 \mathrm{~g} \mathrm{~kg}^{-1}\right)$, which, after conversion, represents for three year the carbon loss of $1.260 \mathrm{t} \mathrm{ha}^{-1}$ in Elymus and $1.125 \mathrm{t} \mathrm{ha}^{-1}$ in Sida in the top soil $(0.3 \mathrm{~m})$.

The content of organic soil carbon is related to the yield of energy crops and changes in weather conditions. The average year air temperature was above normal during the evaluated experimental period, which was probably a contributing cause for the decline in organic carbon in the soil. A significant negative dependence $(r=-0.31)$ was determined between air temperature during the vegetation periods and organic carbon content in the soil and a positive significant dependence $(r=0.32)$ was found between precipitation during vegetation period and organic carbon content in the soil.

The carbon content of humus compounds increased after three years of Miscanthus $\left(+0.13 \mathrm{~g} \mathrm{~kg}^{-1}\right)$, Arundo and Elymus $\left(+0.08 \mathrm{~g} \mathrm{~kg}^{-1}\right)$ cultivation. On the contrary, the carbon content of humus compounds decreased by $0.06 \mathrm{~g} \mathrm{~kg}^{-1}$ after the three years cultivation of Sida. The increase in humus compounds was related with the significant increase in more stable humic acids. The content of less stable fulvic acids decreased comparatively with the increase in the humic acid content.

The largest decline in soil reaction on average by 0.12 was found in Arundo. The lower decrease in soil reaction was found in Miscanthus, Elymus and Sida, soil reactions in all three crops were comparable (from 0.03 to 0.05 ).

A significant decrease in the available phosphorus content in soil was recorded between the baseline and the final year of the experiment in all monitored energy crops. The lowest decrease was found in Arundo and Miscanthus, higher in the Elymus and the highest in the Sida. Conversely, the available potassium content in the soil was increased. The higher increase of available potassium in the soil was found in Arundo and Elymus and lower in Miscanthus and Sida.

\section{Acknowledgements}

This work was funded by the Ministry of Agriculture and Rural Development of the Slovak Republic in the frame of $\mathrm{R} \& \mathrm{D}$ project.

\section{References}

ALVAREZ, R. - LAVADO, R.S. 1998. Climate, organic matter and clay content relationships in the Pampa and Chaco soils, Argentina. In Geoderma, vol. 83, 1998, no. 1-2, pp. 127-141. DOI: 10.1016/ S0016-7061(97)00141-9

ANDERSON-TEIXEIRA, K. K. - DAVIS, S. C. - MASTERS, M. D. DELUCIA, E. H. 2009. Changes in soil organic carbon under biofuel crops. In GCB Bioenergy, vol. 1, 2009, pp. 75-96. DOI: 10.1111/j.1757-1707.2008.01001.x

BARANČÍKOVÁ, G. - ŠOLTYSOVÁ, B. - KOCO, Š. 2010. Prediction of soil organic carbon stock in conditions of Eastern Slovak Lowland. In Agriculture, vol. 56, 2010, no. 2, pp. 35-43.

BIELEK, P. - JURČOVÁ, O. 2010. Methodology of organic carbon balance and determining organic fertilization of agricultural land. $2^{\text {nd }}$ ed., Bratislava : SSCRI, 2010. 145 p. ISBN 978-80-89128-80-8.

BIZÍK, J. - FECENKO, J. - KOTVAS, F. - LOŽEK, O. 1998. Methodics of fertilization and nutrition of plants. $1^{\text {st }}$ ed., Bratislava : AT Publishing Bratislava, 1998. 112 p. ISBN 80-967812-1-9

CHESWORTH, W. 2008. The Encyclopedia of Soil Science. Dordrecht : Springer, 2008, pp. 91-97.

CLIFTON-BROWN, J.C. - BREUER, J. - JONES, M.B. 2007. Carbon mitigation by the energy crop, Miscanthus. In Global Change Biology, vol. 13, 2007, no. 11, pp. 2296-2307. DOI: 10.1111/j.1365-2486.2007.01438.x

DANIELSEN, F. - BEUKEMA, H. - BURGESS, N.D. - PARISH, F. BRÜHL, C.A. - DONALD, P.F. - MURDIYARSO, D. - PHALAN, B. REIJNDERS, L. - STRUEBING, M. - FITZHERBERT, E.B. 2009. Biofuel plantations on forested lands: double jeopardy for biodiversity and climate. In Conserv. Biol., vol. 23, 2009, no. 2, pp. 348-358. DOI: 10.1111/j.1523-1739.2008.01096.x

DAVIS, S. C. - PARTON, W. J. - DOHLEMAN, F. G. - SMITH, C. M. DEL GROSSO, S. - KENT, A. D. - DELUCIA, E. H. 2010. Comparative biogeochemical cycles of bioenergy crops reveal nitrogen-fixation and low greenhouse gas emissions in a Miscanthus $\times$ giganteus agro-ecosystem. In Ecosystems, vol. 13, 2010, no. 1, pp. 144-156. DOI: 10.1007/s10021-009-9306-9

DON, A. - OSBORNE, B. - HASTINGS, A. - SKIBA, U. - CARTER, M.S. - DREWER, J. - FLESSA, H. - FREIBAUER, A. - HYVÖNEN, N. - JONES, M.B. - LANIGAN, G.J. - MANDER, Ü. - MONTI, A. DJOMO, S.N. - VALENTINE, J. - WALTER, K. - ZEGADA-LIZARAZU, W. - ZENONE, T. 2012. Land-use change to bioenergy production in Europe: implications for the greenhouse gas balance and soil carbon. In GCB Bioenergy, vol. 4, 2012, no. 4, pp. 372-391. DOI: 10.1111/j.1757-1707.2011.01116.x

DONDINI, M. - HASTINGS, A. - SAIZ, G. - JONES, M. B. - SMITH, P. 2009. The potential of Miscanthus to sequester carbon in soils: comparing field measurements in Carlow, Ireland to model predictions. In GCB Bioenergy, vol. 1, 2009, no. 6, pp. 413-425. DOI: 10.1111/j.1757-1707.2010.01033.x

DUFFKOVÁ, R. - KVÍTEK, T. - VOLDŘICHOVÁ, J. 2005. Soil organic carbon and nitrogen characteristics in differently used grasslands at sites with drainage and without drainage. In Plant, Soil Environ., vol. 51, 2005, no. 4, pp. 165-172. 
FECENKO, J. - LOŽEK, O. 2000. Nutrition and fertilization of field crops. $1^{\text {st }}$ ed., Nitra : SUA, 2000. 452 p. ISBN 80-7137-777-5.

GUŠTAFÍKOVÁ, T. et al. 2014. Selected green growth indicators in the Slovak Republic. Banská Bystrica : Slovak Environment Agency, 2014, 50 p. ISBN 978-80-89503-35-3.

HILLIER, J. - WHITTAKER, C. - DAILEY, G. - AYLOTT, M. - CASELLA, E. - RICHTER, G.M. - RICHE, A. - MURPHY, R. - TAYLOR, G. - SMITH, P. 2009. Greenhouse gas emissions from four bioenergy crops in England and Wales: Integrating spatial estimates of yield and soil carbon balance in life cycle analyses. In GCB Bioenergy, vol. 1, 2009, no. 4, pp. 267-281. DOI: 10.1111/j.1757-1707.2009.01021.x

HRAŠKO, J. et al. 1962. Soil analyses. $1^{\text {st }}$ ed., Bratislava : Slovak Publish. Pedol. Lit., 1962. 342 p.

HRIVŇÁKOVÁ, K. - MAKOVNÍKOVÁ, J. - BARANČíKOVÁ, G. - BEZÁK, P. - BEZÁKOVA, Z. - DODOK, R. - GRECO, V. - CHLPÍK, J. - KOBZA, J. - LISTJAK, M. - MALIŠ, J. - PIŠ, V. - SCHLOSSEROVÁ, J. - SLÁVIK, O. - SIRAN, M. 2011. A uniform workflows analysis of soils. Bratislava : Soil Science and Conservation Research Institute, 2011, 136 p. ISBN 978-80-89128-89-1.

HORÁČEK, J. - LEDVINA, R. - ČECHOVÁ, V. - ŠABATKOVÁ O. - KOPEČNÁ, J. - HŘEBEČKOVÁ, J. 2005. Soil organic matter transformation processes in Cambisol under minimum-tillage system : Proceedings of the Scientific Conference. Bratislava : SSCRI, 2005, pp. 155-160. ISBN 80-89128-18-1.

HŮLA, J. - PROCHÁZKOVÁ, B. et al. 2008. Minimizing soil processing. $1^{\text {st }}$ ed., Praha : Profi Press, s.r.o., 2008, 246 p. ISBN 978-80-86726-28-1. KOBZA, J. 2014. Current status and development of soil properties in Slovakia in relation to their conservation and further use. In Proceedings of Soil Science and Conservation research Institute, 2014, no. 36, pp. 111-118.

KOVÁĆIK, P. 2001. Plant nutrition and fertilization. In BÍROVÁ, J. et al. Ecological agriculture at Slovakia, part $2^{\text {nd }}$, Nitra : Agroinšitút, 2001, pp. 20-47. ISBN 80-7139-079-8

KRON, I. - PORVAZ, P. - KRÁLOVÁ-HRICINDOVÁ, A. - TÓTH, Š. SARVAŠ, J. - POLÁK, M. 2017. Green harvests of three perennial energy crops and their chemical composition. In International Journal of Agriculture and Environmental Research, vol. 3, 2017, no. 2, pp. 2870-2883.

LAL, R. 2004. Soil carbon sequestration impacts on global climate change and food security. In Science, vol. 304, 2004, no. 5677, pp. 1623-1627. DOI: 10.1126/science.1097396.
LÜTHI, D. - Le FLOCH, M. - BEREITER, B. - BLUNIER, T. - BARNOLA J.M. - SIEGENTHALER, U. - RAYNAUD, D. - JOUZEL, J. - FISCHER, H. - KAWAMURA, K. - STOCKER, T.F. 2008. High-resolution carbon dioxide concentration record $650,000-800,000$ years before present. In Nature, vol. 453, 2008, no. 7193, pp. 379-382. DOI: 10.1038/nature06949.

MARRIOTT, E.E. - WANDER, M.M. 2006. Total and labile soil organic matter in organic and conventional farming systems. In Soil Sci. Soc. Am. J., vol. 70, 2006, no. 3, pp. 950-959. DOI: 10.2136/ sssaj2005.0241.

MEHLICH, A. 1984. Mehlich 3 soil test extractant: A modification of Mehlich 2 extractant. In Commun. Soil Sci. Plant Anal., vol. 15, 1984 pp. 1409-1416.

SCHNECKENBERGER, K. - KUZYAKOV, Y. 2007. Carbon sequestration under Miscanthus in sandy and loamy soils estimated by natural 13C abundance. In J. Plant Nutr. Soil Sci, vol. 170, 2007, no. 4, pp. 538-542. DOI: 10.1002/jpln.200625111.

SLOVAK REPUBLIC. Act no. 151/2016 coll. on the agrochemical soil testing and storage and use of fertilizers.

SYMANOWICZ, B. - KALEMBASA, S. - MALINOWSKA, E. WYSOKINSSKI, A. 2014. Changes in the content of zinc and cobalt in plants and soil, absorption of these elements by goat's rue (Galega orientalis Lam.) biomass and bioaccumulation factors induced by phosphorus and potassium fertilization. In J. Elementol., vol. 19, 2014, no. 1, pp. 219-228. DOI: 10.5601/jelem.2013.18.4.302.

TOBIAŠOVÁ, E. - ŠIMANSKÝ, V. 2009. Quantification of soil properties and their interrelationships affected by anthropogenic activity. $1^{\text {st }}$ ed., Nitra : SUA, 2009. 114 p. ISBN 978-80-552-0196-2.

ZAUJEC, A. - CHLPÍK, J. - NÁDAŠSKÝ, J. - POLLÁKOVÁ, N. TOBIAŠOVÁ, E. 2009. Pedology and basis of geology. Nitra : SUA, 2009, 399 p. ISBN 978-80-552-0207-5

ZHANG, J.B. - SONG, C.C. - WANG, S.M. 2007. Dynamics of soil organic carbon and its fractions after abandonment of cultivated wetlands in northeast China. In Soil Till. Res., vol. 96, 2007, no. 1-2, pp. 350-360. DOI: 10.1016/j.still.2007.08.006.

ZIMMERMANN, J. - DAUBER, J. - JONES, M.B. 2012. Soil carbon sequestration during the establishment phase of Miscanthus $x$ giganteus: a regional-scale study on commercial farms using $13 \mathrm{C}$ natural abundance. In GCB Bioenergy, vol. 4, 2012, no. 4, pp. 453461. DOI: 10.1111/j.1757-1707.2011.01117.x. 